\title{
SERS Investigation on Oligopeptides Used as Biomimetic Coatings for Medical Devices
}

\author{
Michele Di Foggia ${ }^{1} * \mathbb{C}^{\mathbb{C}}$, Vitaliano Tugnoli ${ }^{1}$, Stefano Ottani ${ }^{2}$, Monica Dettin ${ }^{3} \mathbb{C}$, Annj Zamuner ${ }^{3}$, \\ Santiago Sanchez-Cortes ${ }^{4}\left(\mathbb{D}\right.$, Daniele Cesini ${ }^{5}$ and Armida Torreggiani ${ }^{2}(\mathbb{D}$ \\ 1 Dipartimento di Scienze Biomediche e Neuromotorie, Università di Bologna, 40126 Bologna, Italy; \\ vitaliano.tugnoli@unibo.it \\ 2 Istituto per la Sintesi Organica e la Fotoreattività, Consiglio Nazionale delle Ricerche (ISOF-CNR), \\ 40129 Bologna, Italy; stefano.ottani@isof.cnr.it (S.O.); armida.torreggiani@isof.cnr.it (A.T.) \\ 3 Dipartimento di Ingegneria Industriale, Università di Padova, 35131 Padova, Italy; \\ monica.dettin@unipd.it (M.D.); annj.zamuner@unipd.it (A.Z.) \\ 4 Instituto de Estructura de la Materia, Consejo Superior de Investigaciones Cientificas (CSIC), \\ 28006 Madrid, Spain; s.sanchez.cortes@csic.es \\ 5 Dipartimento CNAF, Istituto Nazionale di Fisica Nucleare (INFN-CNAF), 40127 Bologna, Italy; \\ daniele.cesini@cnaf.infn.it \\ * Correspondence: michele.difoggia2@unibo.it; Tel.: +39-051-209-4281
}

check for updates

Citation: Di Foggia, M.; Tugnoli, V.; Ottani, S.; Dettin, M.; Zamuner, A.; Sanchez-Cortes, S.; Cesini, D.; Torreggiani, A. SERS Investigation on Oligopeptides Used as Biomimetic Coatings for Medical Devices. Biomolecules 2021, 11, 959. https:// doi.org/10.3390/biom11070959

Academic Editors: Antonio Evidente and Luigi Vitagliano

Received: 27 April 2021

Accepted: 24 June 2021

Published: 29 June 2021

Publisher's Note: MDPI stays neutral with regard to jurisdictional claims in published maps and institutional affiliations.

Copyright: (c) 2021 by the authors. Licensee MDPI, Basel, Switzerland. This article is an open access article distributed under the terms and conditions of the Creative Commons Attribution (CC BY) license (https:// creativecommons.org/licenses/by/ $4.0 /)$.

\begin{abstract}
The surface-enhanced Raman scattering (SERS) spectra of three amphiphilic oligopeptides derived from EAK16 (AEAEAKAK) 2 were examined to study systematic amino acid substitution effects on the corresponding interaction with Ag colloidal nanoparticles. Such self-assembling molecular systems, known as "molecular Lego", are of particular interest for their uses in tissue engineering and as biomimetic coatings for medical devices because they can form insoluble macroscopic membranes under physiological conditions. Spectra were collected for both native and gamma-irradiated samples. Quantum mechanical data on two of the examined oligopeptides were also obtained to clarify the assignment of the prominent significative bands observed in the spectra. In general, the peptide-nanoparticles interaction occurs through the $\mathrm{COO}^{-}$groups, with the amide bond and the aliphatic chain close to the colloid surface. After gamma irradiation, mimicking a free oxidative radical attack, the SERS spectra of the biomaterials show that $\mathrm{COO}^{-}$groups still provide the main peptide-nanoparticle interactions. However, the spatial arrangement of the peptides is different, exhibiting a systematic decrease in the distance between aliphatic chains and colloid nanoparticles.
\end{abstract}

Keywords: amphiphilic oligopeptides; SERS; biomimetic coating; DFT; oligopeptide-surface interaction; oxidative stress

\section{Introduction}

In the field of functional biomaterials, peptides and oligopeptides can provide several advantages at the nanoscale, mainly related to their high biocompatibility, cell permeability, and low immunogenicity [1-3]. The 20 natural L-amino acids can be assembled in vast numbers of combinations to encompass a massive range of properties, making them suitable for applications in entirely different fields, such as hydrogels for extracellular matrix and hybrid materials for biosensing.

The study of the sequences of yeasts' proteins led to the development of synthetic materials promoting cell growth, composed of regularly alternating polar/nonpolar amphiphilic oligopeptides, whose progenitor was EAK16 (AEAEAKAK) ${ }_{2}$, first synthesized by Zhang and co-workers [4-6]. These molecular systems display complementary polar surfaces, viz. two hydrophilic surfaces can interact by positively and negatively charged amino acid residues at physiological $\mathrm{pH}$, which complement each other, favoring the establishment of hydrophobic interactions, dipole electrostatic forces, $\pi-\pi$ stacking, and 
hydrogen bonding. As a result, these compounds are observed to self-assemble into unusually stable $\beta$-sheet structures $[4,5,7]$, giving rise to insoluble macroscopic membranes under physiological conditions, typically favored by monovalent cations [4]. Since their discovery, these systems have also been known as "molecular Lego". In fact, Lego bricks can be assembled only by matching specific sides, a hole-side with a peg-side, similarly to the behavior of these peptide systems where interactions between complementary polar surfaces give rise to remarkably stable secondary structures.

Such self-assembling oligopeptides have shown to possess chemical and physical stability, as confirmed by their resistance to heat and denaturation by several chemical agents and enzymes [4]. They can be easily fabricated in different geometrical shapes [5,7], including vesicles, spherical or elongated micelles, and nanotubes. Moreover, several studies show their ability to provide stable attachments with mammalian cells, supporting cell proliferation and differentiation [8-11]. This set of properties is especially relevant in advanced biotechnological applications, particularly in the nanofabrication of biomedical devices for bone tissue engineering, constituted by $\mathrm{TiO}_{2}$ surfaces supporting self-assembled peptide layers.

Two main points are essential for the materials' long-term applications: the possible chemical modifications of the peptides and the stability of the corresponding self-assemblies under different conditions [12]. Since the inflammatory processes play a crucial role in the early stages of implanting a biomedical device into the body, the reactions at the interface between the biomaterial and the surrounding tissues can strongly affect the success of an implant $[13,14]$. Thus, it is essential to evaluate the structural changes induced in these oligopeptides by the sequence modifications and the interactions with the biological environment containing metal nanoparticles (NPs) $[15,16]$ or $\bullet \mathrm{OH}$ radicals. Free radicals are constantly formed in the human body during cell growth and in chronic inflammation [13,14], and, even if the EAK peptides reduce this inflammatory reaction [7], it cannot be excluded that $\bullet \mathrm{OH}$ radicals at high concentrations alter the biomaterials.

Raman spectroscopy has proven to be an advantageous technique to investigate oligopeptides' structure [17-20], but two limitations have to be considered. Firstly, most biomolecules display intrinsic fluorescence, which in some cases overwhelms the intensity of the Raman signal; secondly, this technique has a relatively low sensitivity in aqueous solutions, such as the physiological environment. Both drawbacks can be overcome using the SERS technique (Surface Enhanced Raman Scattering), based on the studied molecules' interactions with NPs. In SERS experiments, fluorescence is usually quenched, and very low detection limits in a solution can be achieved (up to $10^{-15} \mathrm{M}$ in selected cases, such as Rhodamine $6 \mathrm{G}$ and $10^{-8} \mathrm{M}$ for peptides) [21,22]. Such an enhancement may allow the study of peptides structure at the interface between the biomaterial and body fluids. It might also provide a test for the presence of oligopeptides in the aqueous environment surrounding a metal implant. Besides, information on the packing and orientation (adsorbed structure) of molecules on the metal surface can be obtained by SERS spectra [23] because specific selection rules take place on the surface vibrations (i.e., more significant tensor components oriented along the vertical axis to the metal surface will undergo a higher enhancement due to the larger field in this direction) [24].

In previous works, we reported results on the damages induced by free radicals to biomaterials [19] and on the peptide-metal interactions $[18,20]$. To obtain more profound insights into these factors, in the present paper, we describe a SERS investigation on some oligopeptides derived from EAK16 (hereafter Pept1). In particular, their primary structure was modified by substitution of acid and basic amino acids with others having different chain length: Pept2, Glu $\rightarrow$ Asp substitution (one $\mathrm{CH}_{2}$ less); Pept3, Lys $\rightarrow$ Orn substitution (one $\mathrm{CH}_{2}$ less), and Pept4, where both the previous substitutions were made [17]. Before and after gamma-ray irradiation, these peptides were investigated to study their resistance to free radical stress exposure and if eventual structural changes can modify their interaction with metal NPs. The SERS spectra interpretation was also supported by theoretical quantum mechanical computations in the Density Functional 
Theory framework (DFT). Computations were performed on model systems made up of simplified peptide sequences and silver atoms interacting with different residues along the peptidic chain to obtain adequate band assignments and better identify interactions of the peptides' distinct groups with the metal surface. Theoretical spectra were analyzed in terms of the Potential Energy Distribution (PED), which was used to estimate the contribution of different vibrational modes to the experimental Raman band intensities.

\section{Materials and Methods}

The examined peptides were Pept1: $\mathrm{H}_{2} \mathrm{~N}$-(Ala-Glu-Ala-Glu-Ala-Lys-Ala-Lys) ${ }_{2}-\mathrm{CONH}_{2}$, taken as a reference; Pept2, where the Glu-charged residue was substituted by Asp (one $\mathrm{CH}_{2}$ group less); Pept3, where the Lys-charged residue was substituted by Orn (one $\mathrm{CH}_{2}$ group less); and Pept4, where both charged residues (Glu, Lys) were substituted by Asp and Orn, respectively. Peptides were synthesized as previously reported [17]. Briefly, the peptides were synthesized by using an automated peptide synthesizer via fluorenylmethoxycarbonyl protecting group (FMOC) chemistry, while the cleavage of the peptides and the deprotection of side chains were achieved using trifluoroacetic acid (TFA); the purity of the peptides ranged between 95 and $99 \%$, although small contamination by FMOC used in the synthesis procedure was revealed in the analysis of the solid samples. Conversely, a residual amount of TFA was never found [17-20].

The silver colloid employed in this work was prepared by following Leopold and Lendl's method [20,25]. Briefly, $10 \mathrm{~mL}$ of a $10^{-2} \mathrm{M} \mathrm{AgNO}_{3}$ solution was added dropwise to $90 \mathrm{~mL}$ of a $1.6 \times 10^{-3} \mathrm{M}$ solution of hydroxylamine hydrochloride containing $3.33 \times 10^{-3} \mathrm{M}$ sodium hydroxide. SERS samples were prepared by adding $10 \mu \mathrm{L}$ of the oligopeptide solution to $490 \mu \mathrm{L}$ of the silver colloid in order to reach a final concentration of $10^{-5} \mathrm{M}$; the obtained solution was shaken for $10 \mathrm{~s}$ on a vortex mixer (RX3, Velp Scientifica, Usmate Velate, Italy) before SERS measure. No salt was used as an aggregating agent. AgNPs were characterized by metallic plasmons' resonances in the UV-Vis spectra, showing a maximum at about $405 \mathrm{~nm}$ [20]. Although the NPs were partially aggregated, there were no large clusters, and the isolated NP diameter was of ca. $50 \mathrm{~nm}$, as obtained by the TEM and UV-vis analysis (Figure S1).

SERS spectra were collected on a Renishaw Raman InVia model spectrometer equipped with a Leica microscope electrically cooled CCD camera. Samples were excited by using the $532 \mathrm{~nm}$ laser line provided by a frequency-doubled Nd:YAG laser and a power of $2.5 \mathrm{~mW}$ at the sample. The spectral resolution was set in all cases to $4 \mathrm{~cm}^{-1}$. SERS spectra were registered with a total acquisition of $30 \mathrm{~s}$ for each SERS spectrum and consisted of 4 scans. The concentration of peptides in the solution was about $10^{-5} \mathrm{M}$.

Raman spectra on solid peptides were recorded on a Bruker Multiram FT-Raman spectrometer, equipped with a liquid nitrogen-cooled Ge-diode detector. The spectral resolution was $4 \mathrm{~cm}^{-1}$ and 6000, the number of scans for each spectrum (integration time about four hours). The excitation source was an $\mathrm{Nd}^{3+}$-YAG laser $(1064 \mathrm{~nm}$, about $100 \mathrm{~mW}$ laser power at the sample) in the backscattering $\left(180^{\circ}\right)$ configuration.

The intensity ratios were calculated after a curve fitting analysis was performed using GPL software (Fityk 0.9.0 by Marcin Wojdyr) [26] on the original spectra in the $3020-2800$ and $1200-1000 \mathrm{~cm}^{-1}$ ranges, using the Levenberg-Marquardt algorithm. The curve-fitting procedures' peak profiles were described as a linear combination of Lorentzian and Gaussian functions [27]. A realistic identification of the peak composition elements and their position was carried out using the second derivative of SERS spectra obtained by a 9-point smoothed moving average function.

Reactive species generation, which mimics the conditions of endogenous radical stress, was obtained by $\gamma$-radiolysis. Gamma irradiation was performed on oligopeptide aqueous solutions using a ${ }^{60} \mathrm{Co}$ Gammacell at the dose rate of $\sim 5.0 \mathrm{~Gy} / \mathrm{min}$. In radiolysis of diluted aqueous solutions, the energy of the radiation is deposited in water, leading to the formation of three short-lived species: hydrated electrons $\left(e_{a q}{ }^{-}\right)$, hydroxyl radicals $(\bullet \mathrm{OH})$, and hydrogen atoms $(\bullet \mathrm{H})$. The experimental conditions can be tuned to control and 
select the three short-lived species in their reactivity. For example, by saturating with $\mathrm{N}_{2} \mathrm{O}$ $\left(\sim 0.02 \mathrm{M}\right.$ of $\left.\mathrm{N}_{2} \mathrm{O}\right), e_{a q}{ }^{-}$are efficiently converted into $\bullet \mathrm{OH}\left(\mathrm{k}=9.1 \times 10^{9} \mathrm{M}^{-1} \mathrm{~s}^{-1}\right) ; \bullet \mathrm{OH}$ and $\bullet \mathrm{H}$ radicals account for $90 \%$ and $10 \%$, respectively, of the reactive species [28]. This condition has been used to model oxidative damage occurring in vivo $[29,30]$ and on many proteic systems [31-33].

$$
\begin{gathered}
\mathrm{H}_{2} \mathrm{O}+e^{-} \stackrel{\gamma}{\rightarrow} e_{a q}^{-}+\bullet \mathrm{OH}+\bullet \mathrm{H} \\
e_{a q}^{-}+\mathrm{N}_{2} \mathrm{O}+\mathrm{H}_{2} \mathrm{O} \rightarrow \mathrm{N}_{2}+\bullet \mathrm{OH}+\mathrm{OH}^{-}
\end{gathered}
$$

After gamma irradiation (200 Gy), the peptides were lyophilized, and their Raman and SERS spectra were collected. Lyophilization was performed on a Modulo 4 K Freeze Dryer equipped with an RV8 Rotary Vane Pump (Edwards). The lyophilized product was kept at $-80^{\circ} \mathrm{C}$ until use.

Regarding quantum mechanical calculations, to reduce excessive computational load, they were performed on model systems mimicking the sequence of Pept1, Pept2, and Pept3. Since the original peptide sequences are made up of two identical moieties plus termini, model systems included only a single moiety, whereas the terminal groups were maintained. Thus, Pept1 was reduced to Pept1-r: $\mathrm{H}_{2} \mathrm{~N}$-Ala-Glu-Ala-Glu-Ala-Lys-Ala-Lys- $\mathrm{CONH}_{2}$, Pept2 to Pept2-r: $\mathrm{H}_{2} \mathrm{~N}$-Ala-Asp-Ala-Asp-Ala-Lys-Ala-Lys-CONH${ }_{2}$, and Pept3 to Pept3-r: $\mathrm{H}_{2} \mathrm{~N}$-Ala-Glu-Ala-Glu-Ala-Orn-Ala-Orn-CONH${ }_{2}$. In fact, computations on these shortened sequences led to results able to provide reliable comparisons between experimental and theoretical SERS spectra [20], reducing the total compute time to manageable levels. The $\mathrm{pH}$ value was about 6.5. Marvin suite by ChemAxon (www.chemaxon.com, last accessed on 29 March 2021) was used to estimate the relative abundance of peptides with different protonation states in the colloidal mixtures. Since the $\mathrm{pH}$ of the peptide/Ag-NPs colloidal mixtures was about 6.5 , species with +1 charge were largely dominant $(>90 \%)$.

$\mathrm{Ag}$ colloidal surfaces' interactions were approximated by placing an $\mathrm{Ag}_{2}$ cluster at different positions along the peptide chains, including terminal groups. These positions provided the initial guess for quantum mechanical geometry optimization. The use of $\mathrm{Ag}_{2}$ (the most straightforward silver cluster possible) is justified by its ability to simulate pointto-point interactions, similar to the geometric arrangements allowed by colloidal particles and its ability to exhibit $v \mathrm{Ag}-\mathrm{Ag}$ vibration in the silver colloidal particles. Consequently, the $\mathrm{Ag}_{2}$ cluster can account for directionality and anisotropy in the interactions between oligopeptides and silver particles, reducing the computational burden of a more significant number of heavy atoms [34].

Quantum mechanical calculations were performed in the Density Functional Theory (DFT) framework by the Gaussian09 program [35]. Every complex corresponding to a different position of $\mathrm{Ag}_{2}$ along the Pept1-r, Pept2-r, and Pept3-r chains was optimized. Results for Pept1-r, already published, are reported here for comparison [20]. Different geometries were obtained for Pept2-r (see Tables S1-S4 in Supporting Information, respectively, for the interaction of $\mathrm{Ag}_{2}$ with the $\mathrm{COO}^{-}$group, the amide $\mathrm{C}=\mathrm{O}$ group (two different settings), and the terminal $\mathrm{C}=\mathrm{O}$ group), and for Pept3-r (see Tables S5-S8 in Supporting Information for the interaction of $\mathrm{Ag}_{2}$ with the same settings as for Pept2-r). The wB97XD functional was employed, using a version of Grimme's D2 dispersion model [36]. Computations were performed by the correlation-consistent, polarized, minimally augmented basis set, maugcc-pVDZ, for all atoms except Ag, modeled by the lanl2dz basis set. Based on literature results $[37,38]$, the choice of this particular combination functional/basis set provides a good compromise between speed and accuracy, as required when dealing with large molecular systems. The implicit solvent model approximated the presence of water molecules in SERS experiments. Calculations were performed by the Self-Consistent Reaction Field (SCRF) using the Polarizable Continuum Model (PCM) [39]. Geometry optimizations were carried on in redundant internal coordinates. According to the implementation in Gaussian09, the convergence criterion was met when maximum and root mean square values of forces and next-step displacements were below predefined thresholds. To improve the accuracy of DFT calculations, a tight convergence criterion was used in the Self 
Consistent Field (SCF) stage, and the number of points used in the numerical integration of the functional was set to the ultrafine level. Thus, all DFT calculations employed the keywords "scf=tight" and "Int(grid=Ultrafine)" [35].

Finally, theoretical Raman spectra were obtained by frequency calculations on the optimized geometries. Frequencies were computed in the limit of the harmonic approximation, using the same basis sets and method as in the geometry optimization steps. All computed frequencies were positive, confirming that optimized geometries correspond to minima on the Potential Energy Surface (PES). Possible anharmonic effects [40] were accounted for by linear fitting of the theoretical frequencies to the experimental ones using the SPESCA program [41]. Scaled frequencies were computed as $v_{\text {scaled }}=a+b v_{\text {calculated. Values of a }}$ and $\mathrm{b}$ are reported for each geometry in the Supplementary Materials (Tables S1-S8 in Supporting Information). Interpretation of the theoretical frequency spectra was performed by the Potential Energy Distribution (PED) analysis of the fundamental vibration modes. The program VEDA carried on the procedure [41,42], allowing for identification of the stretching, bending, and local torsion modes for each computed line. All theoretical and experimental obtained parameters are reported in the Supplementary Materials (Tables S1-S8 in Supporting Information).

\section{Results and Discussion}

\subsection{SERS Spectra of the Peptides As-Synthesized}

The SERS spectra of Pept2, 3, and 4 are compared with that of Pept1, the original peptide synthesized by Zhang [4], where acid and/or basic residues have been substituted to obtain the other peptides. At the $\mathrm{pH}$ of the SERS measurements (about 6.5), as well as in the solid form used to record the FT-Raman spectra, the peptides were mainly with the acid residues (i.e., Glu and Asp) in the deprotonated form, while the basic residues (i.e., Lys and Orn) were protonated. Moreover, the terminal amino group was protonated, giving all peptides a net charge at $\mathrm{pH} 6.5$ of +1 since the terminal carboxylate group is in the amide form.

Figure 1 shows the SERS spectra of all peptides normalized to the water stretching band at 3200-3400 $\mathrm{cm}^{-1}$, and Table 1 reports the band assignment of all peptides, according to literature, and the results of the theoretical calculations on Pept1, Pept2, and Pept3 interacting with an $\mathrm{Ag}_{2}$ dimer in different positions and orientations.

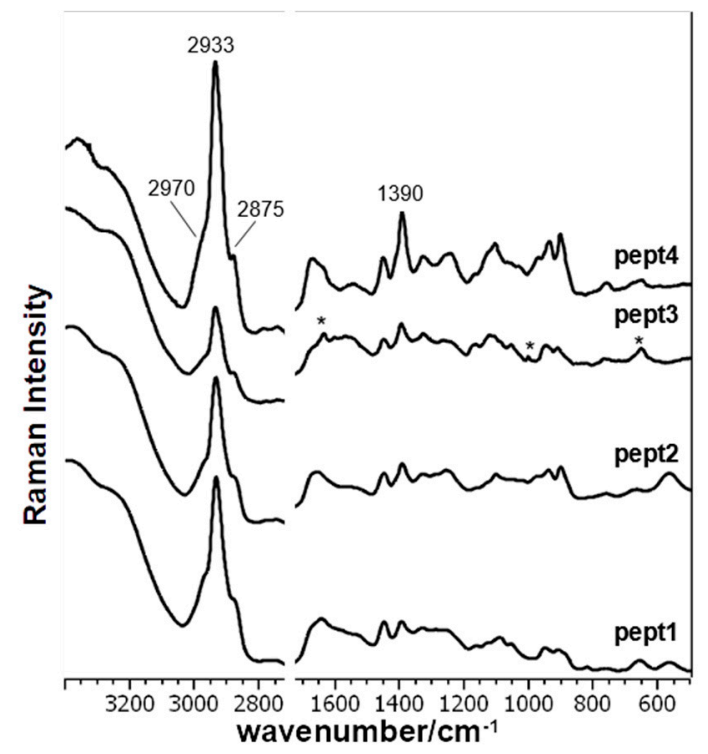

Figure 1. SERS spectra of the examined peptides (Pept2, Pept3, and Pept4) at $10^{-5} \mathrm{M}$ concentration compared with the EAK parent peptide (Pept1). Asterisks $\left(^{*}\right)$ were used to indicate the bands attributed to FMOC used in the synthesis procedure. 


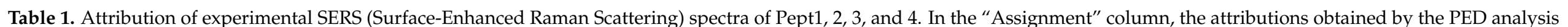

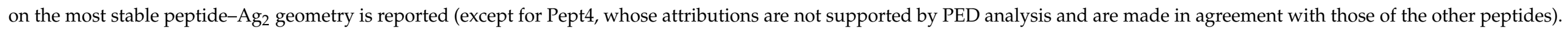

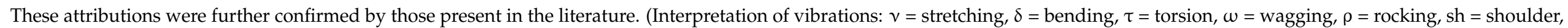
$\mathrm{br}=$ broad, $\mathrm{vs}=$ very strong, $\mathrm{s}=$ strong, $\mathrm{m}=$ medium, $\mathrm{w}=$ weak, $\mathrm{vw}=$ very weak, as = anti-symmetric, $\mathrm{s}=$ symmetric).

\begin{tabular}{|c|c|c|c|c|c|c|c|c|}
\hline \multirow[t]{2}{*}{ Assignment } & \multicolumn{2}{|c|}{$\begin{array}{c}\text { Pept1 } \\
\mathrm{H}_{2} \text { N-Ala-Glu-Ala-Glu-Ala-Lys-Ala- } \\
\text { Lys-Ala-Glu-Ala-Glu-Ala-Lys-Ala-Lys- } \\
\text { CONH }_{2}\end{array}$} & \multicolumn{2}{|c|}{$\underset{\text { Glu } \rightarrow \text { Asp Substitution }}{\text { Asp }}$} & \multicolumn{2}{|c|}{ 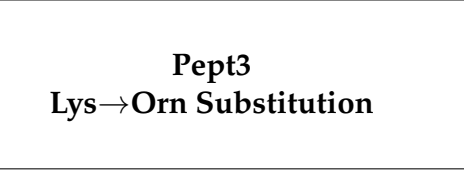 } & \multicolumn{2}{|c|}{$\begin{array}{c}\text { Pept4 } \\
\text { Glu } \rightarrow \text { Asp and Lys } \rightarrow \text { Orn Substitutions }\end{array}$} \\
\hline & SERS & $\begin{array}{c}\text { SERS } \\
\text { Gamma } 200 \text { Gy }\end{array}$ & SERS & $\begin{array}{c}\text { SERS } \\
\text { Gamma } 200 \text { Gy }\end{array}$ & SERS & $\begin{array}{c}\text { SERS } \\
\text { Gamma } 200 \text { Gy }\end{array}$ & SERS & $\begin{array}{c}\text { SERS } \\
\text { Gamma } 200 \text { Gy }\end{array}$ \\
\hline \multirow{3}{*}{$v \mathrm{CH}$ (aliphatic) $[24,43]$} & $2968 \mathrm{sh}$ & $2968 \mathrm{sh}$ & $2968 \mathrm{sh}$ & $2968 \mathrm{sh}$ & $2968 \mathrm{sh}$ & $2968 \mathrm{sh}$ & $2968 \mathrm{sh}$ & $2968 \mathrm{sh}$ \\
\hline & 2934 vs & 2934 vs & 2934 vs & 2934 vs & 2934 vs & 2934 vs & 2934 vs & 2934 vs \\
\hline & $2878 \mathrm{sh}$ & $2875 \mathrm{sh}$ & $2878 \mathrm{sh}$ & $2878 \mathrm{sh}$ & $2878 \mathrm{sh}$ & $2878 \mathrm{sh}$ & $2878 \mathrm{sh}$ & $2878 \mathrm{sh}$ \\
\hline Amide I [43-49] & $1679 \mathrm{sh}$ & $\begin{array}{l}1677 \mathrm{sh} \\
1670 \mathrm{sh}\end{array}$ & $1674 \mathrm{sh}$ & $\begin{array}{c}1668 \mathrm{~m}, \mathrm{sh} \\
1653 \mathrm{~m} \\
(1676+1649 \mathrm{sh}) \\
\end{array}$ & $1679 \mathrm{sh}$ & $\begin{array}{c}1666 \mathrm{~m} \\
(1677+1640 \mathrm{sh})\end{array}$ & $\begin{array}{c}1672 \mathrm{~m} \\
(1680+1654 \mathrm{sh})\end{array}$ & $\begin{array}{c}1671 \mathrm{~m} \\
(1681+1656 \mathrm{sh})\end{array}$ \\
\hline$\delta \mathrm{H}_{2} \mathrm{O}[50]$ & $1644 \mathrm{~m}$ & $\begin{array}{l}1644 \mathrm{~m} \\
1638 \mathrm{sh}\end{array}$ & $1650 \mathrm{~m}$ & & $1650 \mathrm{~m}$ & & & \\
\hline $\begin{array}{l}v_{\text {as }} \mathrm{COO}^{-}[45] \\
\delta \mathrm{NH}_{3}^{+}[51,52] \\
\text { FMOC }[53]\end{array}$ & & & & & $1600 \mathrm{~m}$ & $1603 \mathrm{~m}$ & $1602 \mathrm{sh}$ & $1603 \mathrm{sh}$ \\
\hline$\delta \mathrm{NH}_{3}{ }^{+}$(Lys) $[45,47]$ & $1579 \mathrm{sh}$ & $1575 \mathrm{sh}$ & & $1567 \mathrm{sh}$ & $1579 \mathrm{sh}$ & $1577 \mathrm{sh}$ & $1572 \mathrm{sh}$ & $1575 \mathrm{sh}$ \\
\hline $\begin{array}{c}v_{\mathrm{as}} \mathrm{COO}^{-}[24,44,46] \\
\delta \mathrm{NH}_{3}^{+} \text {(Lys) [54] } \\
\text { Amide II }[43,48] \\
\end{array}$ & $1530 \mathrm{sh}$ & $\begin{array}{l}1551 \mathrm{sh} \\
1531 \mathrm{sh}\end{array}$ & $1555 \mathrm{br}$ & 1542 br & $\begin{array}{l}1568 \mathrm{sh} \\
1542 \mathrm{sh} \\
1531 \mathrm{sh}\end{array}$ & $1551 \mathrm{~m}$ & $\begin{array}{l}1559 \mathrm{sh} \\
1548 \mathrm{br} \\
1535 \mathrm{sh}\end{array}$ & 1559 sh 1548 br \\
\hline$\delta \mathrm{CH}_{2}[43-46,50]$ & $1447 \mathrm{~m}$ & $1447 \mathrm{~m}$ & $1449 \mathrm{~m}$ & $1447 \mathrm{~m}$ & $1447 \mathrm{~m}$ & $1448 \mathrm{~m}$ & $\begin{array}{l}1454 \mathrm{sh} \\
1442 \mathrm{~m}\end{array}$ & $1450 \mathrm{~m}$ \\
\hline$v_{\mathrm{s}} \mathrm{COO}^{-}[24,43-47,49,55]$ & $1393 \mathrm{~m}$ & $1392 \mathrm{~m}$ & $\begin{array}{l}1414 \mathrm{sh} \\
1391 \mathrm{~m}\end{array}$ & $\begin{array}{l}1414 \mathrm{sh} \\
1391 \mathrm{~m}\end{array}$ & $\begin{array}{l}1420 \mathrm{sh} \\
1394 \mathrm{~m}\end{array}$ & $1394 \mathrm{~m}$ & $\begin{array}{l}1415 \mathrm{sh} \\
1391 \mathrm{~m}\end{array}$ & $\begin{array}{l}1417 \mathrm{sh} \\
1391 \mathrm{~m}\end{array}$ \\
\hline$\omega \mathrm{CH}_{2}$ (Lys) $[24,44,45,54]$ & $1329 \mathrm{~m}$ & $1325 \mathrm{~m}$ & $1328 \mathrm{~m}$ & $1326 \mathrm{~m}$ & $1327 \mathrm{w}$ & $1323 \mathrm{~m}$ & $1326 \mathrm{~m}$ & $1326 \mathrm{br}$ \\
\hline
\end{tabular}


Table 1. Cont.

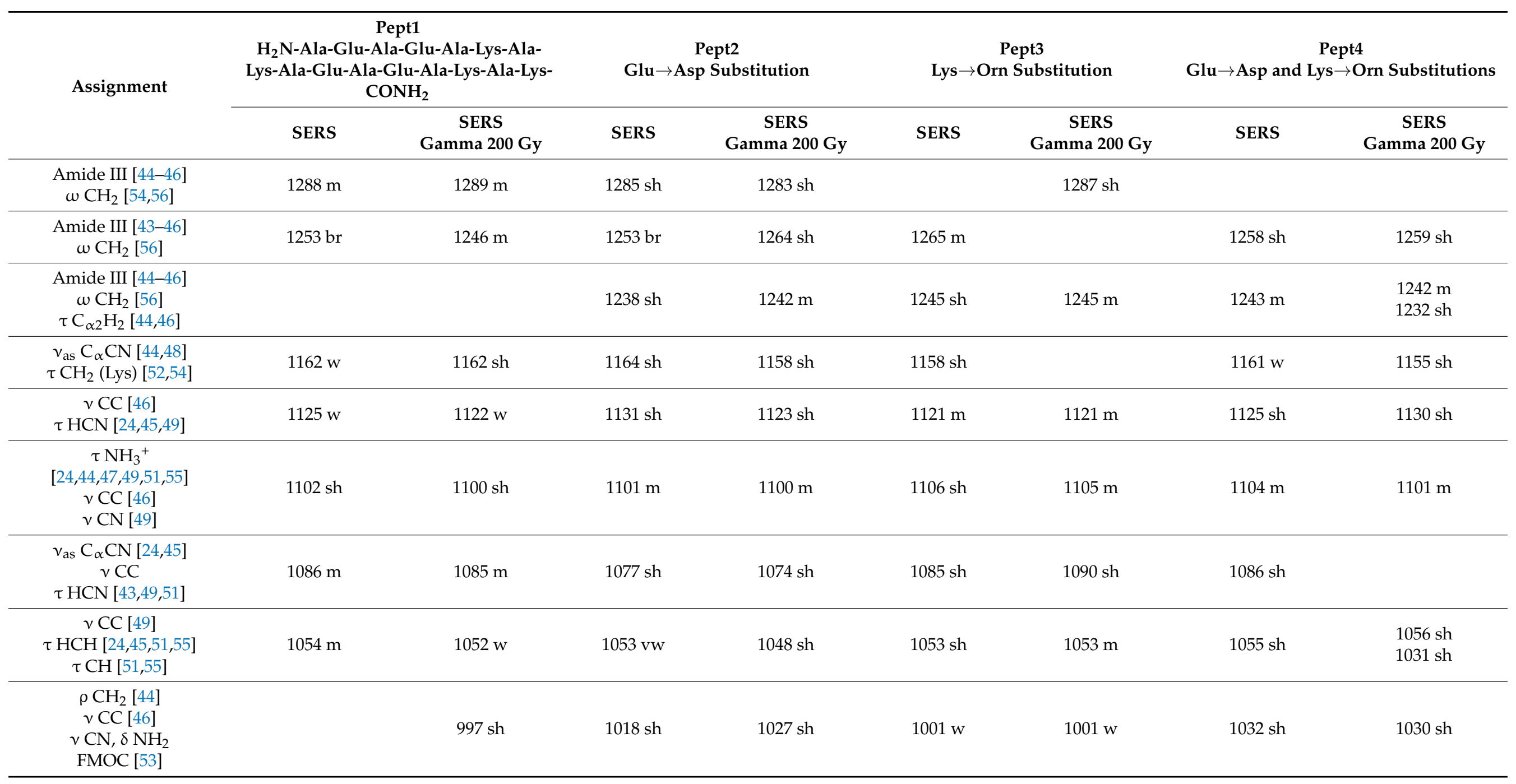


Table 1. Cont.

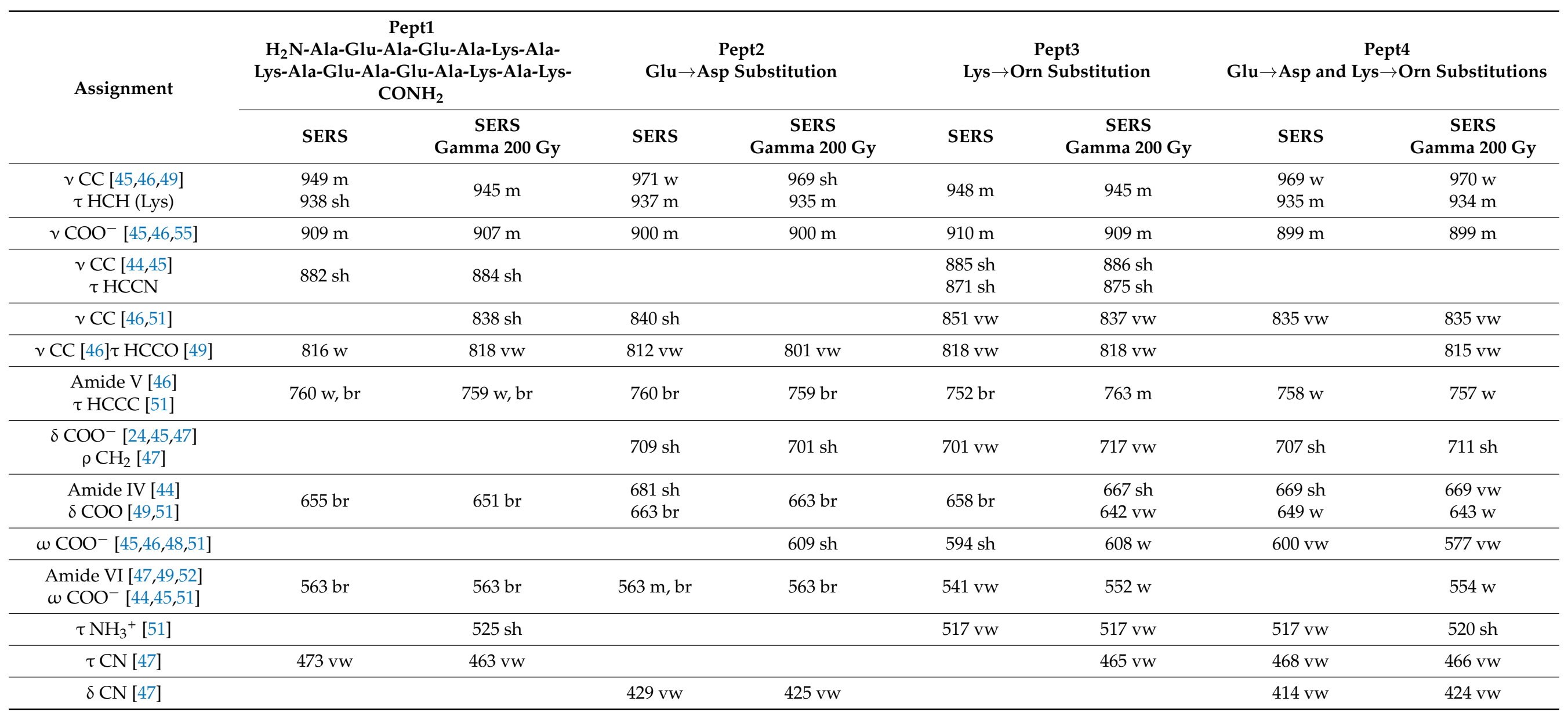


The CH stretching bands in the $3030-2810 \mathrm{~cm}^{-1}$ region are always the strongest bands in all SERS spectra. The peak maximum is at about $2934 \mathrm{~cm}^{-1}$, with two shoulders at 2970 and $2875 \mathrm{~cm}^{-1}$ (Figure S1). Comparing the CH stretching modes $\left(2970-2875 \mathrm{~cm}^{-1}\right.$ ) of the peptides, they appear more intense in Pept 4 than Pept1, whereas they are less intense in Pept2 and Pept3 (Figure 1 and Figure S1). This behavior indicates that the intensity of $\mathrm{CH}$ stretching modes of SERS spectra does not directly correlate with the acid/basic amino acids chain length but is presumably related to the interaction between $\mathrm{CH}_{2}$ groups and their distance and relative orientation with the NPs surface [57]. In fact, the highest relative intensity of the $2930 \mathrm{~cm}^{-1}$ band compared with the water band at $3400-3200 \mathrm{~cm}^{-1}$ was measured in the SERS spectrum of Pept4 (Figure 1 and Figure S1), i.e., which contains the shortest aliphatic chain in the charged amino acids (Asp and Orn). This last finding is also related to the Full Width at Half Maximum (FWHM) of the CH stretching band: the minimum value was measured in Pept 4 at $43 \mathrm{~cm}^{-1}$, while the maximum in Pept1 was $49 \mathrm{~cm}^{-1}$, thus reflecting the $\mathrm{CH}_{2}$ length in charged amino acids (Table 2).

Table 2. Selected parameters of SERS bands involving $\mathrm{CH}$ vibrations before and after exposure to free radical stress (obtained by gamma irradiation): Full Width at Half Maximum (FWHM) of the $v \mathrm{CH}$ band, $\mathrm{I}_{2930} / \mathrm{I}_{2870}$ and $\mathrm{I}_{1060} / \mathrm{I}_{1130}$ intensity ratios indicating the order degree of aliphatic side chains of the oligopeptides [58].

\begin{tabular}{ccccccc}
\hline & \multicolumn{3}{c}{ Not Treated } & \multicolumn{3}{c}{$\begin{array}{c}\text { under Oxidative } \\
\text { Radical Stress }\end{array}$} \\
\cline { 2 - 7 } Sample & $\begin{array}{c}\text { FWHM } \\
\boldsymbol{v} \mathbf{C H} / \mathbf{c m}^{-\mathbf{1}}\end{array}$ & $\mathbf{I}_{\mathbf{2 9 3 0}} / \mathbf{I}_{\mathbf{2 8 7 0}}$ & $\mathbf{I}_{\mathbf{1 0 6 0}} / \mathbf{I}_{\mathbf{1 1 3 0}}$ & $\begin{array}{c}\text { FWHM } \\
\boldsymbol{v} \mathbf{C H} / \mathbf{c m}^{-\mathbf{1}}\end{array}$ & $\mathbf{I}_{\mathbf{2 9 3 0}} / \mathbf{I}_{\mathbf{2 8 7 0}}$ & $\mathbf{I}_{\mathbf{1 0 6 0}} / \mathbf{I}_{\mathbf{1 1 3 0}}$ \\
\hline Pept1 & 49 & 3.0 & 1.4 & 48 & 3.0 & 1.4 \\
\hline Pept2 & 46 & 3.2 & 0.9 & 47 & 3.7 & 0.5 \\
\hline Pept3 & 46 & 3.2 & 2.0 & 46 & 3.3 & 2.4 \\
\hline Pept4 & 43 & 3.2 & 0.9 & 45 & 3.9 & 0.6 \\
\hline
\end{tabular}

The intensity ratio between the 1060 and $1130 \mathrm{~cm}^{-1}$ components of the $\mathrm{CH}$ stretching band has been used to study the order degree and packing of aliphatic chains lipids [58] and, therefore, could give some insights into hydrophobic interactions between side chains; in particular, a decrease of the $\mathrm{I}_{1060} / \mathrm{I}_{1130}$ is a marker of a higher disorder degree in $\mathrm{CH}$ side chains. This intensity ratio increased in Pept3 (2.0), whereas it decreased in Pept2 and Pept4 (0.9) (Table 2), which have the most disordered packaging of the aliphatic chains.

The bands at about 1450 and $1330 \mathrm{~cm}^{-1}$, assigned to the aliphatic chain's deformation modes, are well visible in the SERS spectra of all peptides (Table 1). The former shows some differences only in Pept4, where the peak is centered at $1442 \mathrm{~cm}^{-1}$, and the second derivative shows an additional component at $1454 \mathrm{~cm}^{-1}$ (Figure S2). On the contrary, the latter is different in Pept3: a weak band is observed at $1347 \mathrm{~cm}^{-1}$, with a shoulder at $1330 \mathrm{~cm}^{-1}$ observable in the second derivative spectrum (not shown). Analogously, other bands attributed to the aliphatic chain between 1200 and $850 \mathrm{~cm}^{-1}$ showed many similarities between Pept 2 and Pept 4 , while they are different in Pept 3 . Pept 2 and 4 showed peaks at about 1100, 1030,970, and $940 \mathrm{~cm}^{-1}$ (Figures 2 and 3), while the prominent bands in Pept 3 are located at about 1125, 1053, and $950 \mathrm{~cm}^{-1}$ (Figure 4). These three bands also appear in the SERS spectrum of Pept1 (Figure 5); they could be attributed to the aliphatic chain of glutamic acid, while those described for Pept 2 and 4 (i.e., 1100, 1030, 970, and $\left.940 \mathrm{~cm}^{-1}\right)$, to aspartate. 


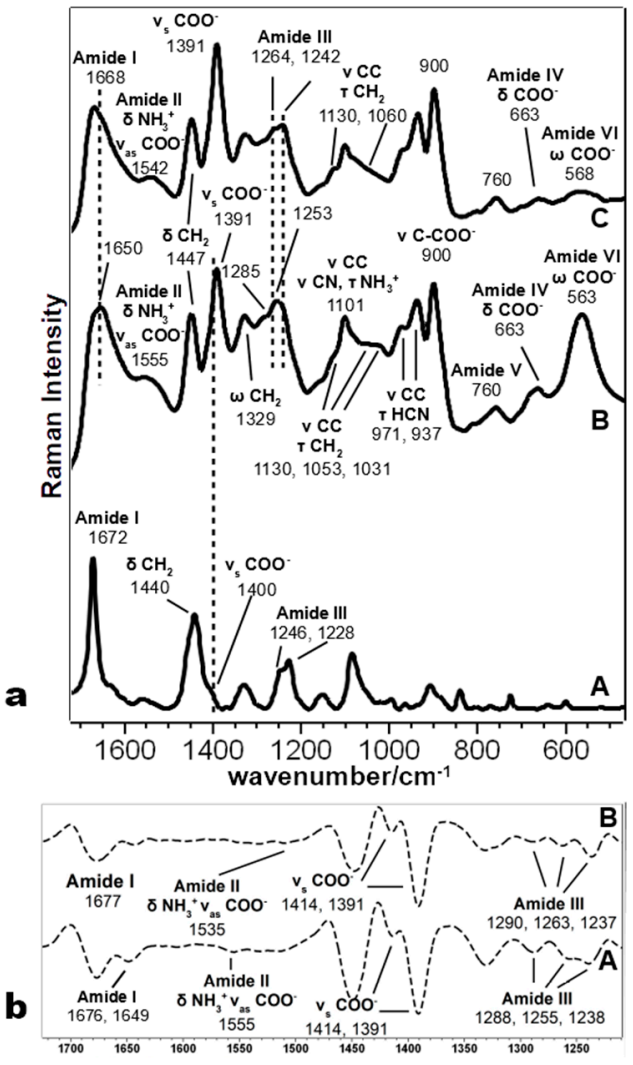

Figure 2. (a) Comparison of the Raman spectrum (A) and SERS spectra of Pept2 as-synthesized (B) and after irradiation (C); (b) second derivative SERS spectra of Pept2 before (A) and after (B) irradiation.

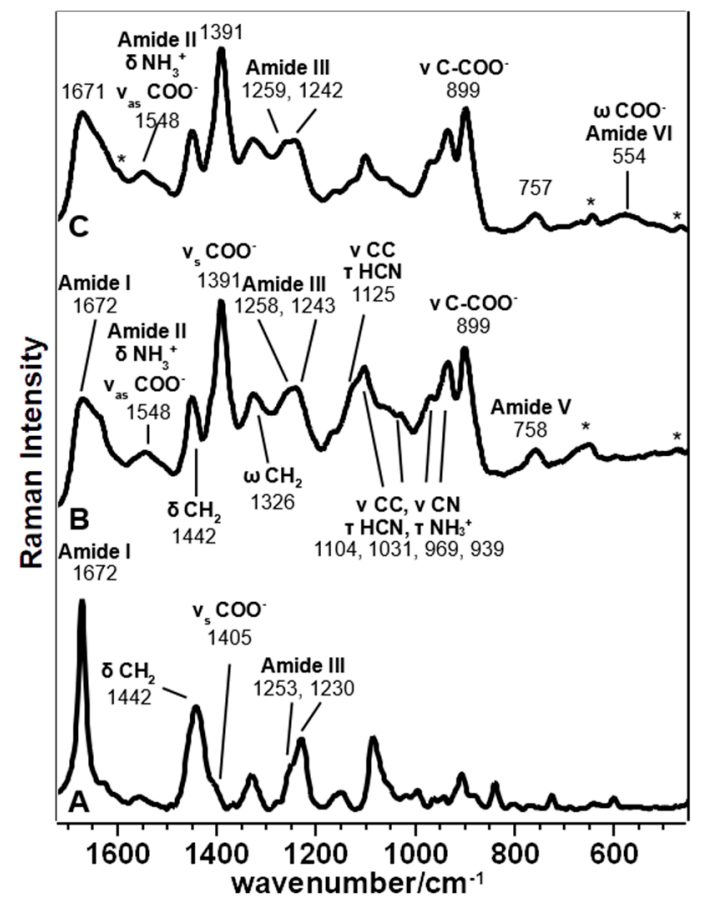

Figure 3. Comparison of the Raman spectrum (A) and SERS spectra of Pept4 as-synthesized (B) and after irradiation $(\mathrm{C})$. Asterisks ${ }^{*}$ ) were used to indicate the bands attributed to FMOC or a contaminant of the solution. 


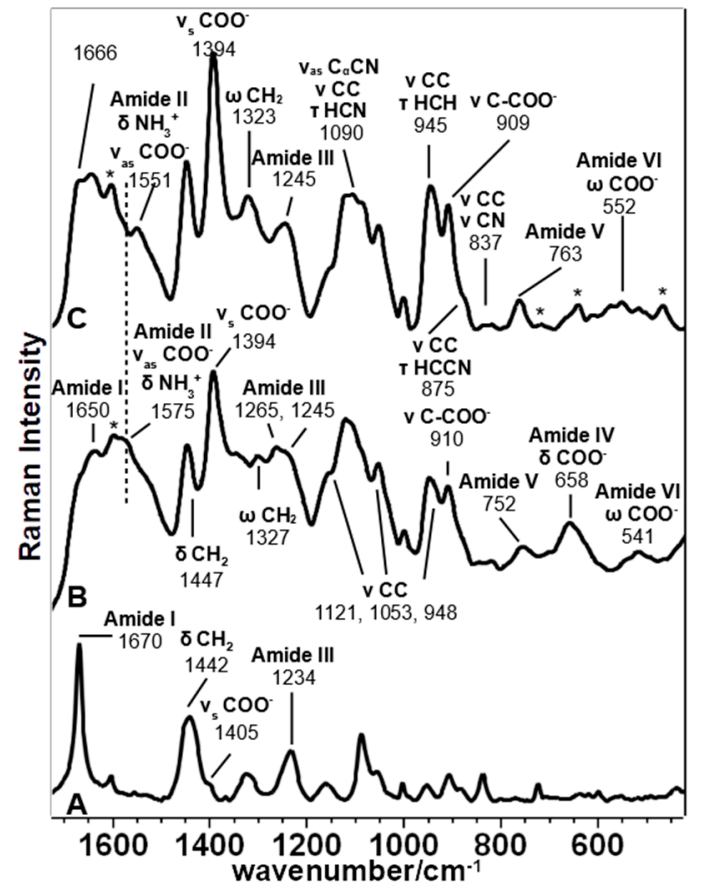

Figure 4. Comparison of the Raman spectrum (A) and SERS spectra of Pept3 as-synthesized (B) and after irradiation $(\mathrm{C})$. Asterisks $\left({ }^{*}\right)$ were used to indicate the bands attributed to FMOC or the solution's contaminant.

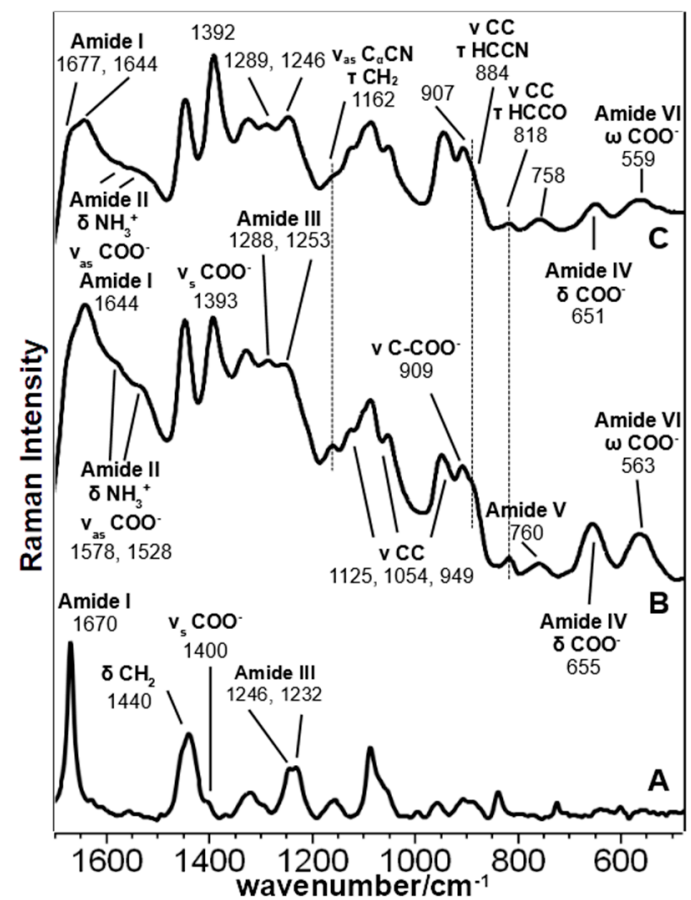

Figure 5. Comparison of the Raman spectrum (A) and SERS spectra of the parent peptide (Pept1) as-synthesized (B) and after irradiation (C).

Regarding Pept3, the presence of three bands, asterisked in Figure 4, at about 1615, 1000 , and $650 \mathrm{~cm}^{-1}$, are not significant because they are due to FMOC, used to synthesize the peptides [54]. 
Regarding the peptide bonds, their SERS bands' intensities (particularly Amide I) usually decreased compared to carboxylate bands, indicating a different position for the polypeptidic chain regarding the metal surface. Moreover, theoretical results are consistent with this hypothesis: the optimized geometries of Pept2-r interacting with the Ag dimer through the peptidic bond (Table 3) showed a distance of 2.35-2.36 A between Ag and the carbonyl groups (Tables S1-S4).

Table 3. Comparison of the relative stability for the interactions of the $\mathrm{Ag}_{2}$ cluster with different peptide groups. $\mathrm{E}_{\text {et }}$ is the sum of electronic and thermal energies $\left(\mathrm{kJ} \mathrm{mol}^{-1}\right)$. Lower values of $\Delta \mathrm{E}$ correspond to more favorable interactions.

\section{Peptide- $\mathrm{Ag}_{2}$ Conformations}

Pept1-r: $\mathrm{Ag}_{2} /-\mathrm{COO}^{-} 1$ st setting $\mathrm{E}_{\mathrm{et}}=-8,218,083.1$

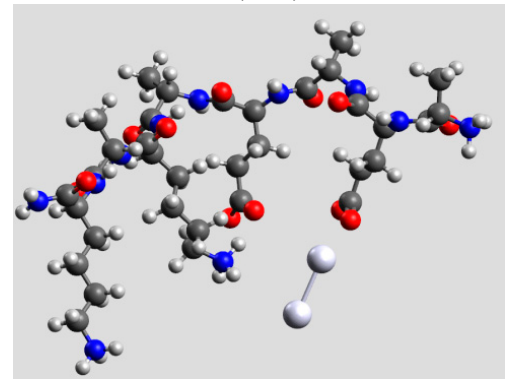

$\Delta \mathrm{E}=0$

Pept1-r: $\mathrm{Ag}_{2} /-\mathrm{C}=\mathrm{O}_{\text {chain }}$ $\mathrm{E}_{\text {et }}=-8,218,058.4$

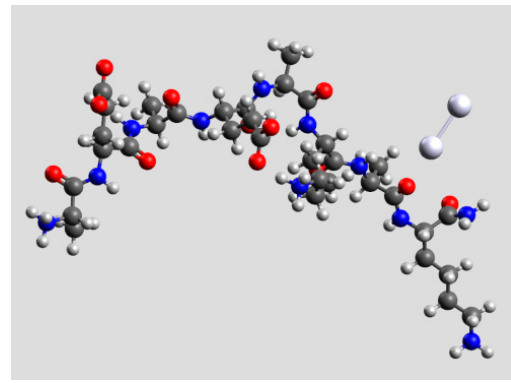

$\Delta \mathrm{E}=24.67$
Pept1-r: $\mathrm{Ag}_{2} /-\mathrm{COO}^{-}$2nd setting $\mathrm{E}_{\mathrm{et}}=-8,218,064.5$

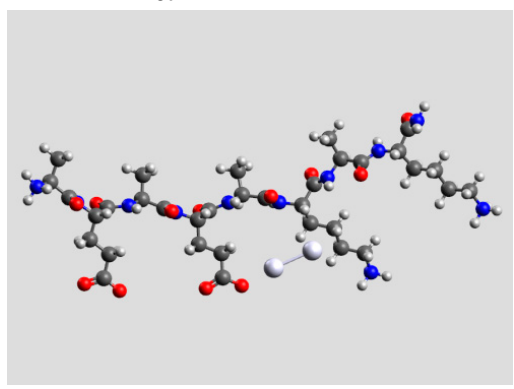

$\Delta \mathrm{E}=18.64$

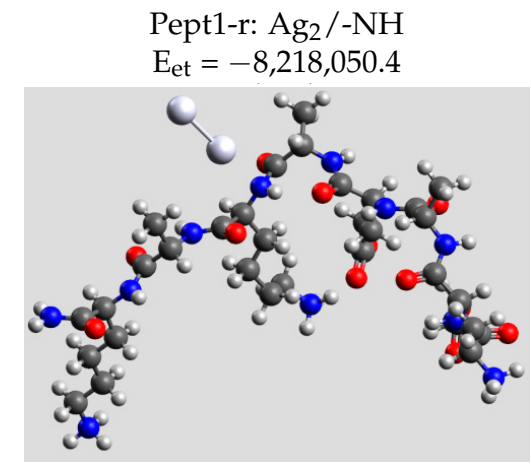

$\Delta \mathrm{E}=32.70$

Pept1-r: $\mathrm{Ag}_{2} /-\mathrm{C}=\mathrm{O}_{\text {terminal }}$, $\mathrm{E}_{\mathrm{et}}=-8,218,041.1$

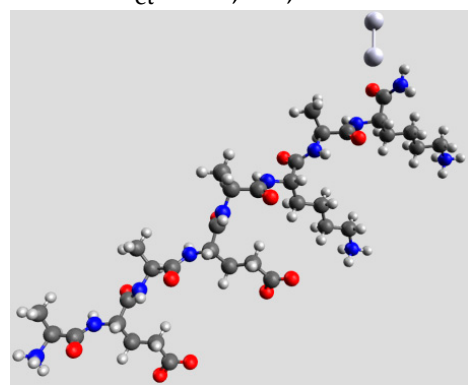

$\Delta \mathrm{E}=41.99$ 
Table 3. Cont.

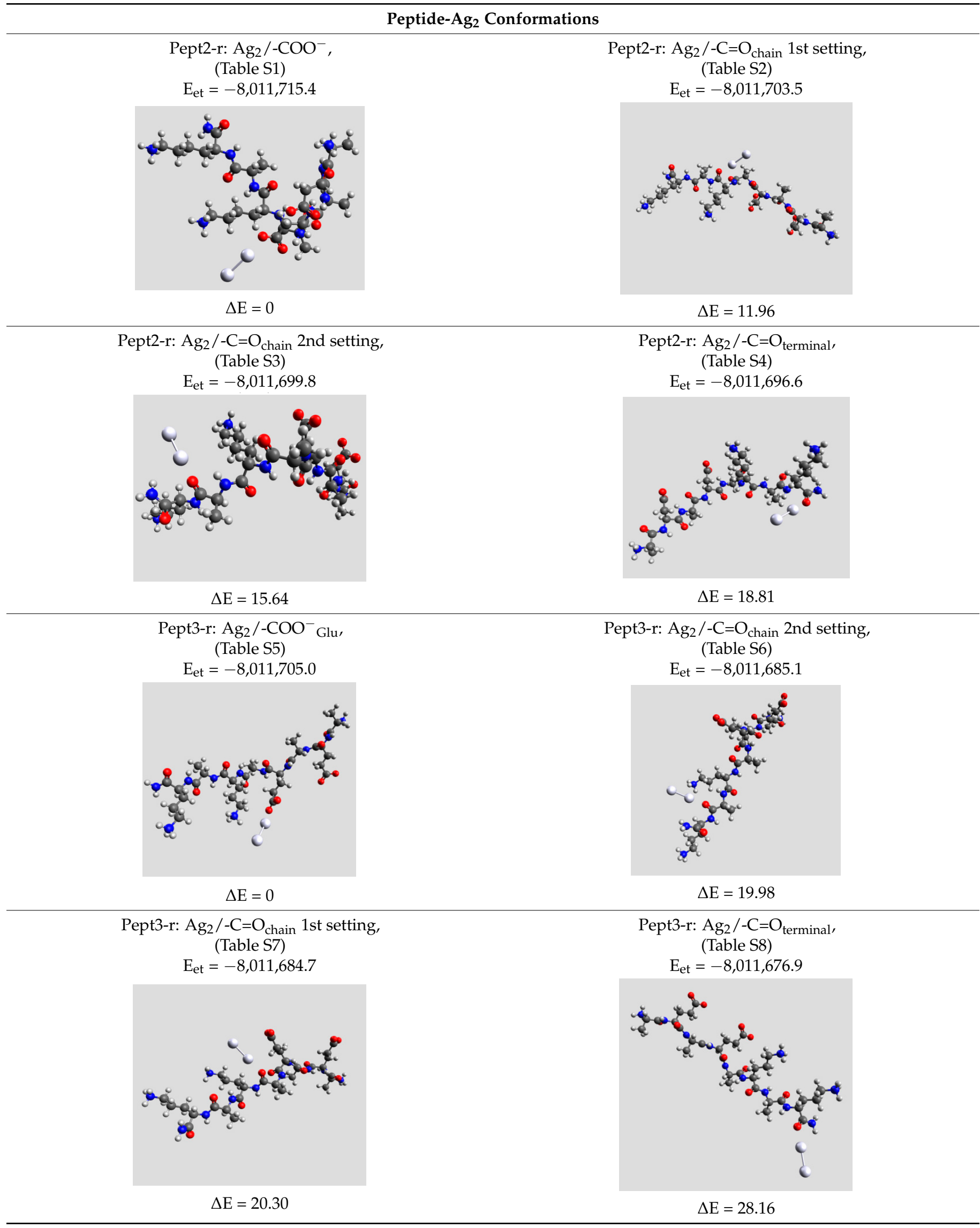


Due to the overlap of the high number of components under the Amide I and III bands, significantly when turns and other structures could scatter in the same or nearby regions, it is judicious not to assign these components to a specific secondary structure, but to use them only to check if changes in the overall peptide structure take place.

The most intense SERS band in the Amide I region of Pept2 (Figure 2a) appeared at $1650 \mathrm{~cm}^{-1}$, with a shoulder at a higher wavenumber. Using the second derivative spectra, these two components were more clearly visible at 1649 and $1676 \mathrm{~cm}^{-1}$ (Figure 2b), but since SERS spectra are recorded in solution, a significant contribution of the $1640 \mathrm{~cm}^{-1}$ water band was overlapped and should be considered. Moreover, in the Amide III bands, some components could be identified at 1288,1255 , and $1238 \mathrm{~cm}^{-1}$ (see Figure $2 \mathrm{~b}$ ), indicating the presence of different peptides' secondary structure motifs, compatible with other studies of peptides interacting with NPs [59]. Since this oligopeptide has a prevalent $\beta$-sheet secondary structure in the solid phase [17], it is evident that the interaction with NPs notably changed its folding.

Analogously, the presence of different components both in the Amide I and III bands for Pept3 (Amide I 1679 and $1650 \mathrm{~cm}^{-1}$; Amide III: 1265 and $1245 \mathrm{~cm}^{-1}$ ) and Pept4 (Amide I: $1672 \mathrm{~cm}^{-1}$ with a shoulder at $1647 \mathrm{~cm}^{-1}$; Amide III: at 1258 and $1243 \mathrm{~cm}^{-1}$ ) (Figure 3 and Figure S2) suggest that those peptides adopt quite different foldings due to the interactions with the metal.

The SERS spectrum of Pept2 (Glu $\rightarrow$ Asp substitution, one $\mathrm{CH}_{2}$ less), shown in more detail in Figure 2a, displays a notable enhancement of the bands attributed to carboxylate vibrations than its Raman spectrum, suggesting that carboxylate groups directly interact with the nanoparticles. The most prominent band of carboxylate groups appeared at $1391 \mathrm{~cm}^{-1}$ (symmetric stretching mode $v_{\mathrm{s}} \mathrm{COO}^{-}$), intensified and red-shifted of about $10 \mathrm{~cm}^{-1}$, compared to the Raman spectrum. This band intensification can be attributed to the $\mathrm{COO}^{-}$proximity to the surface and the occurrence of a charge transfer mechanism [60]. This result agrees with the DFT calculation (Table 3), where the interaction between the $\mathrm{Ag}_{2}$ dimer and the carboxylate group of Glu residue gives rise to the most stable system.

These spectral changes can also be observed in other SERS bands attributable to $\mathrm{COO}^{-}$vibrations, such as the $\vee \mathrm{C}_{-} \mathrm{COO}^{-}, \delta \mathrm{COO}^{-}$and $\delta \mathrm{COO}^{-}$vibration modes (Table 1 ). The first gave rise to a band visible at $910 \mathrm{~cm}^{-1}$ in the Pept1 and Pept3 spectra (Figure 5; Figure 4, respectively), which shifted toward lower wavenumbers in the Pept 2 and Pept 4 spectra $\left(900 \mathrm{~cm}^{-1}\right.$, Figure 2; Figure 3, respectively) due to the acidic amino acid substitution; the second one was at $654 \mathrm{~cm}^{-1}$ in the spectrum of Pept1 (Figure 5), shifted to $663 \mathrm{~cm}^{-1}$ in the spectrum of Pept2 $\left(\delta \mathrm{COO}^{-}\right.$, Figure 2$)$; the last gave rise to a broad and intense band at about $563 \mathrm{~cm}^{-1}\left(\delta \mathrm{COO}^{-}\right.$, Figure 5$)[58,59]$. These last two bands were mixed with amide motions (Table 1), as suggested by the PED analysis results of the different optimized geometries of the $\mathrm{Ag}_{2}$-Pept2-r systems (Tables S1-S4). The most stable Pept2$\mathrm{Ag}_{2}$ systems were obtained when the Ag dimer was set close to the carboxylate group of an Asp residue (Table 3). The presence and enhancement of all these $\mathrm{COO}^{-}$bands indicate that these functional groups lie perpendicular or nearly perpendicular to the silver surface. This result agrees with the absence of both $\delta \mathrm{COO}^{-}$and $\omega \mathrm{COO}^{-}$bands (720 and $620 \mathrm{~cm}^{-1}$, respectively), [55,61], since these vibrations are observed when the $\mathrm{COO}^{-}$groups lie parallel to the metal surface.

To better understand the interaction mechanism of Pept 2 with the NPs, the second derivative spectrum was obtained (Figure $2 b$ ). It displayed a $v_{\text {as }} \mathrm{COO}^{-}$band at $1555 \mathrm{~cm}^{-1}$ and two main components of the $v_{\mathrm{S}} \mathrm{COO}^{-}$mode in the $1390-1414 \mathrm{~cm}^{-1}$ region, suggesting that not all the $\mathrm{COO}^{-}$groups interact in the same way with the $\mathrm{Ag}$ particles. The presence of both types of vibrations allowed us to calculate a value of $\Delta v=\left(v_{\text {as }} \mathrm{COO}^{-}-v_{\mathrm{S}} \mathrm{COO}^{-}\right)$ $164 \mathrm{~cm}^{-1}$, corresponding to bridging bidentate coordination [18,62]. Comparing the Pept2 SERS spectrum with its parent Pept1 (Figure 5), a very similar trend can be found regarding the $\mathrm{COO}^{-}-\mathrm{Ag}_{2}$ interaction, except for the notable intensity increase of the $563 \mathrm{~cm}^{-1}$ band $\left(\mathrm{COO}^{-}\right.$wagging) visible in the Pept2 spectrum. Some authors [63] observed that this deformation band's intensity is sensitive to the incident laser's polarization; thus, this 
band's strength in the Pept2 spectrum could be attributed to the orientation of carboxylate groups toward the Ag nanoparticles.

Theoretical calculations showed that the Ag dimer lies in the same plane as the carboxylate group at a distance of $2.29 \AA$ from the oxygen atom (see molecular geometries in Table 3), suggesting the setting up of bidentate chelation over the closer Ag atom.

Analogously, Pept3 (Lys $\rightarrow$ Orn substitution, one $\mathrm{CH}_{2}$ less) showed a significant enhancement of the bands attributed to carboxylate vibrations, indicating the direct interaction of this functional group with NPs (Figure 4). Table 3 reports a similar orientation of the $\mathrm{Ag}_{2}$ dimer in both peptides when close to carboxylate groups, as indicated by a similar $\Delta v$ value $\left(174 \mathrm{~cm}^{-1}\right)$. In this peptide, the $\mathrm{COO}^{-}$wagging band is feeble and appears at $541 \mathrm{~cm}^{-1}$, i.e., red-shifted of about $20 \mathrm{~cm}^{-1}$ compared to Pept2. The red shifting can be explained in agreement with the IR spectrum of amino acids, where the deformation band of the carboxylate group was visible at $553 \mathrm{~cm}^{-1}$ for Aspartic acid and $536 \mathrm{~cm}^{-1}$ for glutamic acid [61].

Additionally, the SERS spectrum of Pept 4 (Glu $\rightarrow$ Asp substitution, Lys $\rightarrow$ Orn substitution, both one $\mathrm{CH}_{2}$ less), reported in Figure 3, shows bands attributable to $\mathrm{COO}^{-}$ group very similar to those observed for Pept2, except for the absence of the $\omega \mathrm{COO}^{-}$at about $560 \mathrm{~cm}^{-1}$. In this case, the $\Delta v$ value is $157 \mathrm{~cm}^{-1}$, thus corresponding to bridging bidentate coordination, as observed for Pept2 [18,62].

\subsection{SERS Spectra of the Peptides after Irradiation}

The SERS spectra of the peptides exposed to $\bullet \mathrm{OH}$ radical attack were compared with the nonirradiated ones. As a general rule, SERS spectra evidenced fewer differences between irradiated and nonirradiated peptides than what was observed in the solid phase [19] due to the different experimental conditions: i.e., low peptide concentration in aqueous solution and interaction with silver nanoparticles.

\subsubsection{Peptide 1}

The parent peptide, upon radical exposure, showed many variations on amides and carboxylate bands, together with some changes in the aliphatic chain bands (Figure 5). In more detail, Amides I and III increased after irradiation and were visible at 1677 and $1246 \mathrm{~cm}^{-1}$, respectively. Low wavenumber Amide IV $\left(650 \mathrm{~cm}^{-1}\right)$ and Amide VI $\left(560 \mathrm{~cm}^{-1}\right)$ were affected by irradiation: these complex vibration modes are mainly associated with $\mathrm{C}=\mathrm{O}$ bending [20]s; therefore, their reduced intensity, as well as that of the Amide I band, may indicate a variation in the orientation and distance between the amide carbonyl group and Ag nanoparticles. These intensity changes may also reflect a variation of the orientation of carboxylic groups whose bending contributes to these low wavenumber bands; in fact, the irradiated SERS spectrum showed an intensity increase in the $1393 \mathrm{~cm}^{-1}$ band (symmetric stretching) with a decrease of the 1580-1530 $\mathrm{cm}^{-1}$ range (asymmetric stretching, mixed with Amide II and $\mathrm{NH}_{3}{ }^{+}$bending). Those changes also reflect on aliphatic chain bands at 1162,884 , and $818 \mathrm{~cm}^{-1}$, which reduced their intensity upon irradiation.

\subsubsection{Peptide 2}

In Pept2 (Figure 2a), the radical attack induced many changes at the secondary structure level: in fact, both Amide I and Amide III bands showed many differences. The former band shifted its maximum from 1650 to $1668 \mathrm{~cm}^{-1}$, with a central component of the second derivative spectrum at $1677 \mathrm{~cm}^{-1}$ (Figure $2 \mathrm{~b}$ ). The latter showed a principal peak at $1242 \mathrm{~cm}^{-1}\left(1253 \mathrm{~cm}^{-1}\right.$ before the radical attack $)$, with a shoulder at $1264 \mathrm{~cm}^{-1}$ (1285 $\mathrm{cm}^{-1}$ before the radical attack), and with an additional component (from the second derivative spectrum, Figure $2 \mathrm{~b}$ ) at $1288 \mathrm{~cm}^{-1}$, confirming that the prevailing secondary structure was changed. Another interesting feature is the increase of the relative intensity of the symmetric stretching band of $\mathrm{COO}^{-}$groups at $1391 \mathrm{~cm}^{-1}$, while the asymmetric band shifted from 1555 to $1542 \mathrm{~cm}^{-1}$. Moreover, the deformation bands at $663 \mathrm{~cm}^{-1}$ and mostly $563 \mathrm{~cm}^{-1}$ showed a significant decrease as previously observed in Pept1: therefore, 
similar considerations about the carboxylic group orientation toward Ag nanoparticles could be drawn.

The most intense bands involving aliphatic groups $\left(\mathrm{CH}\right.$ stretching at $2930 \mathrm{~cm}^{-1}$, together with the $\mathrm{CH}$ bending at $1447 \mathrm{~cm}^{-1}$ ) showed an increased relative intensity without band shifts (Figure 2a and Figures S1 in the Supplementary Info). However, Table 2 shows that the $I_{2930} / I_{2870}$ ratio, marker of the order degree, and packing of aliphatic chains increased from 3.2 to 3.7. This last effect could be linked to the increased content of $\beta$-sheet structure, an ordered structure that may increase the aliphatic chains' degree order. The decreased $\mathrm{I}_{1060} / \mathrm{I}_{1130}$ ratio further confirms the previous finding of the aliphatic chains increased order (Table 2). The mixed modes bands in the $1200-800 \mathrm{~cm}^{-1}$ region, most of which involves $\mathrm{CH}$ and $\mathrm{CC}$ bonds, showed many shifts and intensity changes; however, due to the complexity of these modes (for attributions, see Table 1 and Tables S1-S7), they could not be used to discuss the orientation of aliphatic chains further.

\subsubsection{Peptide 3}

After the radical attack, the most significant variation in Pept3 was the notable increase in CH stretching bands' relative intensity at $2930-2870 \mathrm{~cm}^{-1}$ (Figure S1) without any variation of the $\mathrm{I}_{2930} / \mathrm{I}_{2870}$ ratio (Table 2). Accordingly, the $\mathrm{CH}$ bending band at $1447 \mathrm{~cm}^{-1}$ also increased, together with the $1323 \mathrm{~cm}^{-1}\left(\omega \mathrm{CH}_{2}\right)$; additionally, the bands at $1090 \mathrm{~cm}^{-1}$, $945 \mathrm{~cm}^{-1}, 875 \mathrm{~cm}^{-1}$, and $837 \mathrm{~cm}^{-1}$, all related to skeletal C-C, C-N, and C-H bonds, increased (Figure 4). Carboxylate group bands generally increased too, particularly the $v_{\mathrm{S}} \mathrm{COO}^{-}$at $1394 \mathrm{~cm}^{-1}$ and the $v \mathrm{CCOO}^{-}$at $909 \mathrm{~cm}^{-1}$, while the mixed vibration modes involving amides showed a decrease/shift. In fact, the asymmetric stretching mode showed a decrease in the $1575 \mathrm{~cm}^{-1}$ component and an increase in the $1551 \mathrm{~cm}^{-1}$ one, and the $\delta \mathrm{COO}^{-}$band at $658 \mathrm{~cm}^{-1}$ almost disappeared, while the $\omega \mathrm{COO}^{-}$at 541 shifted to $552 \mathrm{~cm}^{-1}$ upon radical attack. All these changes reflect a different orientation of carboxyl groups of the irradiated peptide that can also be affected by variation occurring to the secondary structure adopted by the peptide. Moreover, amides bands showed changes in their position and relative intensity. In the Amide I region, the component at $1677 \mathrm{~cm}^{-1}$ (second derivative spectrum, Figure S3) increased, as previously observed in Pept1 and Pept2. Interestingly, the Amide V band at $752 \mathrm{~cm}^{-1}$ increased its intensity and shifted to $763 \mathrm{~cm}^{-1}$; since this vibrational mode has a significant contribution from the out of plane bending of the amide $\mathrm{N}-\mathrm{H}$ bond, this change reflects a closer interaction between Ag nanoparticles and this chemical group, as also suggested by the increase of the bands mentioned above at 1090, 945, 875, and $837 \mathrm{~cm}^{-1}$ involving the C-N bond, too. This effect may explain the unexpected increase of the $\mathrm{I}_{1060} / \mathrm{I}_{1130}$ ratio (Table 2) that is not correlated to an increased order degree of the aliphatic chains (see the $\mathrm{I}_{2930} / \mathrm{I}_{2870}$ ratio, Table 2).

\subsubsection{Peptide 4}

This last peptide was poorly affected by the radical attack; thus, it appears as one of the most resistant biomaterials to oxidative stress conditions (Figure 3). Bands attributed to the $\mathrm{COO}^{-}$group showed a slight reduction of their relative intensity (the components of the asymmetric stretching band at 1570 and $1535 \mathrm{~cm}^{-1}$, the symmetric stretching band at $1391 \mathrm{~cm}^{-1}$, and the $\mathrm{C}-\mathrm{COO}^{-}$stretching band at $899 \mathrm{~cm}^{-1}$ ), while the mixed band at $554 \mathrm{~cm}^{-1}$ was observed only in the spectrum of the peptide after irradiation $\left(\mathrm{COO}^{-}\right.$and Amide VI). All the amide bands were poorly affected by irradiation: both peak maxima and the second derivative components remained almost unchanged in the Amide I, III, and V bands. More intense variations affected the aliphatic chains: $\mathrm{CH}$ stretching at $2930 \mathrm{~cm}^{-1}$ increased in wavenumber and relative intensity than the $2870 \mathrm{~cm}^{-1}$ component (Table 2 and Figure S1 in the Supplementary material). The $1125 \mathrm{~cm}^{-1}$ band ( $\vee \mathrm{CC}$ and $\tau \mathrm{HCN}$ ) and the $\mathrm{CH}$ bending at $1450 \mathrm{~cm}^{-1}$ decreased; this last band lost the component at $1442 \mathrm{~cm}^{-1}$ after the radical attack (Figure S2). These findings may indicate the Asp residues' partial decarboxylation, which may have affected the $\mathrm{I}_{1060} / \mathrm{I}_{1130}$ ratio (Table 2). 


\section{Conclusions}

The SERS technique allows detection of all the examined peptides at a $10^{-5} \mathrm{M}$ concentration, proving adequate identification in a biological environment. The peptide-Ag colloid interaction is prevalent due to COO- groups, with the peptidic bond tilted and close to the silver surface even after free radical stress exposure of the biomaterials, in agreement with the quantum mechanical data indicating that the most stable optimized geometries for the analyzed peptides are obtained by silver-carboxylate interaction. The variation of charged amino acid in the peptide sequence slightly affected the orientation of carboxylate groups without altering the primary interaction mechanism with the Ag nanoparticles. These interactions, coupled with the aqueous environment, deeply affected the secondary structure adopted by peptides compared to the solid phase.

After the oxidative free radical attack, all the peptides' spectra indicated a different spatial disposition of the aliphatic chains and an increased aliphatic chain order that also affected the position of the amides bands, sensible to the secondary structure. Two different causes can induce the observed modifications on hydrophobic chains: the self-assembly in a more ordered structure, as occurs for Pept2, or by a partial decarboxylation, as in Pept4.

Supplementary Materials: The following are available online at https:/ / www.mdpi.com/article/10 .3390 /biom11070959/s1, Figure S1: UV-Vis spectrum and a TEM image (in the inset) of the silver colloid used in the study; Figure S2: SERS spectra of the examined peptides before and after $\bullet \mathrm{OH}$ radical attack (the latter are indicated with the letter " $\mathrm{i}$ ", indicating the experimental treatment, irradiation) in the 3450-2800 $\mathrm{cm}^{-1}$ spectral range; Figure S3: Second derivative SERS spectra of Pept4 before (A) and after $\bullet \mathrm{OH}$ radical attack (B) in the $1700-1350 \mathrm{~cm}^{-1}$ spectral range; Figure S4: Second derivative SERS spectra of Pept3 before (A) and after $\bullet \mathrm{OH}$ radical attack (B) in the $1700-1350 \mathrm{~cm}^{-1}$ spectral range; Table S1: Interpretation of Raman SERS Spectrum of Oligopeptide (AlaAsp) ${ }_{2}(\text { AlaLys })_{2}$ $\left(\mathrm{Ag}_{2} / \mathrm{COO}^{-}\right)$; Table S2: Interpretation of Raman SERS Spectrum of Oligopeptide (AlaAsp $)_{2}(\text { AlaLys })_{2}$ $\left(\mathrm{Ag}_{2} /-\mathrm{C}=\mathrm{O}\right.$ in the peptidic chain); Table S3: Interpretation of Raman SERS Spectrum of Oligopeptide $(\mathrm{AlaAsp})_{2}(\mathrm{AlaLys})_{2}\left(\mathrm{Ag}_{2} /-\mathrm{C}=\mathrm{O}\right.$ in the Peptidic Chain, 2nd Setting); Table S4: Interpretation of Raman SERS Spectrum of Oligopeptide (AlaAsp) $)_{2}$ (AlaLys) $)_{2}\left(\mathrm{Ag}_{2} /-\mathrm{C}=\mathrm{O}\right.$, terminal); Table S5: Interpretation of Raman SERS Spectrum of Oligopeptide (AlaGlu $)_{2}(\mathrm{AlaOrn})_{2}\left(\mathrm{Ag}_{2} /-\mathrm{COO}^{-} \mathrm{Glu}\right)$; Table S6: Interpretation of Raman SERS Spectrum of Oligopeptide (AlaGlu) $)_{2}(\mathrm{AlaOrn})_{2}\left(\mathrm{Ag}_{2} /-\mathrm{C}=\mathrm{O}\right.$ in the peptidic chain, 2nd Setting); Table S7: Interpretation of Raman SERS Spectrum of Oligopeptide $(\mathrm{AlaGlu})_{2}(\mathrm{AlaOrn})_{2}\left(\mathrm{Ag}_{2} /-\mathrm{C}=\mathrm{O}\right.$ in the peptidic chain, 1st setting); Table S8: Interpretation of Raman SERS Spectrum of Oligopeptide (AlaGlu $)_{2}(\text { AlaOrn })_{2}\left(\mathrm{Ag}_{2} /-\mathrm{C}=\mathrm{O}\right.$ terminal).

Author Contributions: Conceptualization, M.D.F. and A.T.; methodology, M.D.F., S.S.-C. and A.T.; software, M.D.F. and V.T.; investigation, M.D.F., S.O., D.C., M.D., A.Z. and S.S.-C.; data curation, M.D.F., D.C. and S.O.; writing—original draft preparation, M.D.F., S.O. and V.T.; writing-review and editing, S.S.-C., M.D., A.Z., D.C. and A.T. All authors have read and agreed to the published version of the manuscript.

Funding: This research received no external funding.

Institutional Review Board Statement: Not Applicable.

Informed Consent Statement: Not Applicable.

Data Availability Statement: The data presented in this study are available in the Supplementary materials (Tables S1-S8).

Acknowledgments: The authors wish to warmly thank Anna Tinti for her fruitful collaboration on data analysis and paper reviewing and editing and wish her to enjoy a well-deserved retirement.

Conflicts of Interest: The authors declare no conflict of interest.

\section{References}

1. Wang, J.; Liu, K.; Xing, R.; Yan, X. Peptide self-assembly: Thermodynamics and kinetics. Chem. Soc. Rev. 2016, 45, 5589-5604. [CrossRef] [PubMed]

2. Avakyan, N.; Greschner, A.A.; Aldaye, F.; Serpell, C.J.; Toader, V.; Petitjean, A.; Sleiman, H.F. Reprogramming the assembly of unmodified DNA with a small molecule. Nat. Chem. 2016, 8, 368-376. [CrossRef] 
3. Adler-Abramovich, L.; Gazit, E. The physical properties of supramolecular peptide assemblies: From building block association to technological applications. Chem. Soc. Rev. 2014, 43, 6881-6893. [CrossRef] [PubMed]

4. Zhang, S.; Holmes, T.; Lockshin, C.; Rich, A. Spontaneous assembly of a self-complementary oligopeptide to form a stable macroscopic membrane. Proc. Natl. Acad. Sci. USA 1993, 90, 3334-3338. [CrossRef] [PubMed]

5. Zhang, S.; Holmes, T.; Di Persio, C.M.; Hynes, R.O.; Su, X.; Rich, A. Self-complementary oligopeptide matrices support mammalian cell attachment. Biomaterials 1995, 16, 1385-1393. [CrossRef]

6. Zhang, S. Emerging biological materials through molecular self-assembly. Biotechnol. Adv. 2002, 20, 321-339. [CrossRef]

7. Holmes, T.C.; de Lacalle, S.; Su, X.; Liu, G.; Rich, A.; Zhang, S. Extensive neurite outgrowth and active synapse formation on self-assembling peptide scaffolds. Proc. Natl. Acad. Sci. USA 2000, 97, 6728-6733. [CrossRef] [PubMed]

8. Li, J.; Du, X.; Hashim, S.; Shy, A.; Xu, B. Aromatic-aromatic interactions enable $\alpha$-helix to ß-sheet transition of peptides to form supramolecular hydrogels. J. Am. Chem. Soc. 2017, 139, 71-74. [CrossRef]

9. Lampel, A.; Ulijn, R.V.; Tuttle, T. Guiding principles for peptide nanotechnology through directed discovery. Chem. Soc. Rev. 2018, 47, 3737-3758. [CrossRef]

10. Li, X.; Fei, J.; Xu, Y.; Li, D.; Yuan, T.; Li, G.; Wang, C.; Li, J. A photoinduced reversible phase transition in a dipeptide supramolecular assembly. Angew. Chem. Int. Ed. 2018, 57, 1903-1907. [CrossRef]

11. Yuan, T.; Xu, Y.; Fei, J.; Xue, H.; Li, X.; Wang, C.; Fytas, G.; Li, J. The ultrafast assembly of a dipeptide supramolecular organogel and its phase transition from gel to crystal. Angew. Chem. Int. Edit. 2019, 131, 11189-11194. [CrossRef]

12. Christofferson, A.J.; Al-Garawi, Z.S.; Todorova, N.; Turner, J.; Del Borgo, M.P.; Serpell, L.C.; Aguilar, M.I.; Yarovsky, I. Identifying the coiled-coil triple helix structure of $ß$-peptide nanofibers at atomic resolution. ACS Nano 2018, 12, 9101-9109. [CrossRef]

13. Anderson, J.M. Biological Responses to Materials. Annu. Rev. Mater. Res. 2001, 31, 81-110. [CrossRef]

14. Bryan, N.; Ashwin, H.; Smart, N.; Bayon, Y.; Wohlert, S.; Hunt, J.A. Reactive oxygen species (ROS) a family of fate deciding molecules pivotal in constructive inflammation and wound healing. Eur. Cells Mater. 2012, 24, 249-265. [CrossRef] [PubMed]

15. Bontidean, I.; Kumar, A.; Csöregi, E.; Galaev, I.Y.; Mattiasson, B. Highly sensitive novel biosensor based on an immobilized lac repressor. Angew. Chem. Int. Edit. 2001, 40, 2676-2678. [CrossRef]

16. Marvin, J.S.; Hellinga, H.W. Conversion of a maltose receptor into a zinc biosensor by computational design. Proc. Natl. Acad. Sci. USA 2001, 98, 4955-4960. [CrossRef] [PubMed]

17. Tinti, A.; Di Foggia, M.; Taddei, P.; Torreggiani, A.; Dettin, M.; Fagnano, C. Vibrational study of auto-assembling oligopeptides for biomedical applications. J. Raman Spectrosc. 2008, 39, 250-259. [CrossRef]

18. Di Foggia, M.; Taddei, P.; Torreggiani, A.; Dettin, M.; Tinti, A. Interactions between Oligopeptides and oxidized Titanium Surfaces detected by vibrational spectroscopy. J. Raman Spectrosc. 2011, 42, 276-285. [CrossRef]

19. Di Foggia, M.; Torreggiani, A.; Taddei, P.; Dettin, M.; Tinti, A. Spectroscopic investigation on the structural modifications induced by radical stress on oligopeptides for tissue engineering. J. Raman Spectrosc. 2013, 44, 1446-1450. [CrossRef]

20. Di Foggia, M.; Ottani, S.; Torreggiani, A.; Dettin, M.; Sanchez-Cortes, S.; Cesini, D.; Tinti, A. Surface-enhanced Raman scattering and quantum-mechanical calculations on auto-assembling oligopeptides. J. Raman Spectrosc. 2018, 49, 982-996. [CrossRef]

21. Yang, S.; Dai, X.; Boschitsch Stogin, B.; Wong, T.S. Ultrasensitive surface-enhanced Raman scattering detection in common fluids. Proc. Natl. Acad. Sci. USA 2016, 113, 268-273. [CrossRef] [PubMed]

22. Negri, P.; Sarver, S.A.; Schiavone, N.M.; Dovichi, N.J.; Schultz, Z.D. Online SERS detection and characterization of eight biologically active peptides separated by capillary zone electrophoresis. Analyst 2015, 140, 1516-1522. [CrossRef] [PubMed]

23. Podstawka-Proniewicz, E.; Kudelski, A.; Kim, Y.; Proniewicz, L.M. Structure of Monolayers Formed from Neurotensin and Its Single-Site Mutants: Vibrational Spectroscopic Studies. J. Phys. Chem. B 2011, 115, 6709-6721. [CrossRef]

24. Suh, J.S.; Moskovits, M. Surface-enhanced Raman spectroscopy of amino acids and nucleotide bases adsorbed on silver. J. Am. Chem. Soc. 1986, 108, 4711-4718. [CrossRef]

25. Leopold, N.; Lendl, B. A new method for fast preparation of highly Surface-Enhanced Raman Scattering (SERS) active silver colloids at room temperature by reduction of silver nitrate with hydroxylamine hydrochloride. J. Phys. Chem. B 2003, 107, 5723-5727. [CrossRef]

26. Wojdyr, M. Fityk: A general-purpose peak fitting program. J. Appl. Crystallogr. 2010, 43, 1126-1128. [CrossRef]

27. Jun, S.; Hong, Y.; Imamura, H.; Ha, B.Y.; Bechhoefer, J.; Chen, P. Self-assembly of the ionic peptide EAK16: The effect of charge distributions on self-assembly. Biophys. J. 2004, 87, 1249-1259. [CrossRef]

28. Ross, A.B.; Mallard, W.G.; Helman, W.P.; Buxton, G.V.; Huie, R.E.; Neta, P. NDRL-NIST Solution Kinetics Database-Ver. 3; Notre Dame Radiation Laboratory, Notre Dame, IN and NIST Standard Reference Data: Gaithersburg, MD, USA, 1998.

29. Garrison, W.M. Reaction mechanisms in the radiolysis of peptides, polypeptides, and proteins. Chem. Rev. 1987, 87, 381-398. [CrossRef]

30. Winterbourn, C.C. Toxicity of iron and hydrogen peroxide: The Fenton reaction. Toxicol. Lett. 1995, 82-83, 969-974. [CrossRef]

31. Jurasekova, Z.; Tinti, A.; Torreggiani, A. Use of Raman spectroscopy for the identification of radical-mediated damages in human serum albumin. Anal. Bioanal. Chem. 2011, 400, 2921-2931. [CrossRef]

32. Krämer, A.C.; Torreggiani, A.; Davies, M.J. Effect of oxidation and protein unfolding on cross-linking of $\beta$-lactoglobulin and $\alpha$-lactalbumin. J. Agric. Food Chem. 2017, 65, 10258-10269. [CrossRef] 
33. Torreggiani, A.; Tinti, A.; Jurasekova, Z.; Capdevila, M.; Saracino, M.; Di Foggia, M. Structural Lesions of Proteins Connected to Lipid Membrane Damages Caused by Radical Stress: Assessment by Biomimetic Systems and Raman Spectroscopy. Biomolecules 2019, 9, 794; [CrossRef]

34. Bonora, S.; Benassi, E.; Maris, A.; Tugnoli, V.; Ottani, S.; Di Foggia, M. Raman and SERS study on atrazine, prometryn and simetryn triazine herbicides. J. Mol. Struct. 2013, 1040, 139-148. [CrossRef]

35. Frisch, M.J.; Trucks, G.W.; Schlegel, H.B.; Scuseria, G.E.; Robb, M.A.; Cheeseman, J.R.; Scalmani, G.; Barone, V.; Mennucci, B.; Petersson, G.A.; et al. Gaussian 09, Revision D.01; Gaussian, Inc.: Wallingford, CT, USA, 2009.

36. Chai, J.D.; Head-Gordon, M. Long-range corrected hybrid density functionals with damped atom-atom dispersion corrections. Phys. Chem. Chem. Phys. 2008, 10, 6615-6620. [CrossRef] [PubMed]

37. James, W.H.; Buchanan, E.G.; Muller, C.W.; Dean, J.C.; Kosenkov, D.; Slipchenko, L.V.; Guo, L.; Reidenbach, A.G.; Gellman, S.H.; Zwier, T.S. Evolution of amide stacking in larger $\gamma$-peptides: Triamide H-bonded cycles. J. Phys. Chem. A 2011, 115, 13783-13798. [CrossRef] [PubMed]

38. Papajak, E.; Leverentz, H.R.; Zheng, J.J.; Truhlar, D.G. Perspectives on basis sets beautiful: Seasonal plantings of diffuse basis functions. J. Chem. Theory Comput. 2009, 5, 1197-1202. [CrossRef] [PubMed]

39. Tomasi, J.; Mennucci, B.; Cammi, R. Quantum mechanical continuum solvation models. Chem. Rev. 2005, 105, 2999-3094. [CrossRef] [PubMed]

40. Merrick, J.P.; Moran, L.D.; Radom, L. An evaluation of harmonic vibrational frequency scale factors. J. Phys. Chem. A 2007, 111, 11683-11700. [CrossRef] [PubMed]

41. Jamróz, M.H.; Dobrowolski, J.C.; Brzozowski, R. Vibrational modes of 2,6-, 2,6- and 2,3-diisopropylnaphthalene. A DFT study. J. Mol. Struct. 2006, 787, 172-183. [CrossRef]

42. Jamróz, M.H. Vibrational energy distribution analysis (VEDA): Scopes and limitations. Spectrochim. Acta A Mol. Biomol. Spectrosc. 2013, 114, 220-230. [CrossRef]

43. Podstawka, E.; Kudelski, A.; Kim, Y.; Proniewicz, L.M. Potential-Dependent Studies on the interaction between phenylalaninesubstituted bombesin fragments and roughened $\mathrm{Ag}$, Au, and $\mathrm{Cu}$ electrode surface. J. Phys. Chem. B 2011, 115, 7097-7108. [CrossRef]

44. Herne, T.M.; Ahern, A.M.; Garrell, R.L. Surface-enhanced Raman spectroscopy of peptides: Preferential N-terminal adsorption on colloidal silver. J. Am. Chem. Soc. 1991, 113, 846-854. [CrossRef]

45. Xiaojuan, Y.; Huaimin, G.; Jiwei, W. Surface-enhanced Raman spectrum of Gly-Gly adsorbed on the silver colloidal surface. J. Mol. Struct. 2010, 977, 56-61. [CrossRef]

46. Podstawka, E. Effect of amino acid modifications on the molecular structure of adsorbed and nonadsorbed bombesin 6-14 fragments on an electrochemically roughened silver surface. J. Raman Spectrosc. 2008, 39, 1290-1305. [CrossRef]

47. Aliaga, A.E.; Aguayo, T.; Garrido, C.; Clavijo, E.; Hevia, E.; Gomez-Jeria, J.S.; Leyton, P.; Campos-Vallette, M.M.; Sanchez-Cortes, S. Surface-enhanced Raman scattering and theoretical studies of the C-terminal peptide of the B-subunit human chorionic gonadotropin without linked carbohydrates. Biopolymers 2010, 95, 135-143. [CrossRef]

48. Malek, K.; Makowski, M.; Krolikowska, A.; Bukowska, J. Comparative studies on IR, Raman, and surface-enhanced Raman scattering spectroscopy of dipeptides containing $\Delta$ Ala and $\Delta$ Phe. J. Phys. Chem. B 2012, 116, 1414-1425. [CrossRef]

49. Pienpinijtham, P.; Proniewicz, E.; Kim, Y.; Ozaki, Y.; Lombardi, J.R.; Proniewicz, L.M. Molecular orientation of neurotensin and its single-site mutants on a colloidal silver surface: SERS studies. J. Phys. Chem. C 2012, 116, 16561-16572. [CrossRef]

50. Chen, X.G.; Schweitzer-Stenner, R.; Asher, S.A.; Mirkin, N.G.; Krimm, S. Vibrational Assignments of trans-N-methylacetamide and some of its deuterated isotopomers from band decomposition of IR, visible and resonance Raman Spectra. J. Phys. Chem. 1995, 99, 3074-3083. [CrossRef]

51. Ramaswamy, S.; Rajaram, R.K.; Ramakrishnan, V. Vibrational spectra of bis(L-ornithinium) chloride nitrate sulfate. J. Raman Spectrosc. 2005, 36, 12-17. [CrossRef]

52. Garrido, C.; Aliaga, A.E.; Gomez-Jeria, J.S.; Clavijo, R.E.; Campos-Vallette, M.M.; Sanchez-Cortes, S. Adsorption of oligopeptides on silver nanoparticles: Surface-enhanced Raman scattering and theoretical studies. J. Raman Spectrosc. 2010, 41, 1149-1155. [CrossRef]

53. Levine, M.S.; Ghosh, M.; Hesser, M.; Hennessy, N.; DiGuiseppi, D.M.; Adler-Abramovich, L.; Schweitzer-Stenner, R. Formation of peptide-based oligomers in dimethylsulfoxide: Identifying the precursor of fibril formation. Soft Matter 2020, 16, 7860-7868. [CrossRef] [PubMed]

54. Aliaga, A.E.; Ahumada, H.; Sepulveda, K.; Gomez-Jeria, J.S.; Garrido, C.; Weiss-Lopez, B.E.; Campos-Vallette, M.M. SERS, molecular dynamics and molecular orbital studies of the MRKDV peptide on silver and membrane surfaces. J. Phys. Chem. C 2011, 115, 3982-3989. [CrossRef]

55. Castro, J.L.; Sanchez-Cortes, S.; Garcia Ramos, J.V.; Otero, J.C.; Marcos, J.I. Surface-enhanced Raman spectroscopy of $\gamma-$ aminobutyric acid on silver colloid surfaces. Biospectroscopy 1998, 3, 449-455. [CrossRef]

56. Stewart, S.; Fredericks, P.M. Surface-enhanced Raman spectroscopy of peptides and proteins adsorbed on an electrochemically prepared silver surface. Spectrochim. Acta A 1999, 55, 1615-1640. [CrossRef]

57. Ignatjev, I.; Proniewicz, E.; Proniewicz, L.M.; Niaura, G. Effect of potential on temperature-dependent SERS spectra of neuromedin B on Cu electrode. Phys. Chem. Chem. Phys. 2013, 15, 807-815. [CrossRef] 
58. Tu, A.T. Raman spectroscopy in biology. In Principles and Applications; John Wiley and Sons: New York, NY, USA, 1982; pp. 187-233.

59. Sevilla, P.; Sánchez-Cortés, S.; García-Ramos, J.V.; Feis, A. Concentration-controlled formation of myoglobin/gold nanosphere aggregates. J. Phys. Chem. B 2014, 118, 5082-5092. [CrossRef]

60. Matei, A.; Drichko, N.; Gompf, B.; Dressel, M. Far-infrared spectra of amino acids. Chem. Phys. 2005, 316, 61-71. [CrossRef]

61. Stewart, S.; Fredericks, P.M. Surface-enhanced Raman spectroscopy of amino acids adsorbed on an electrochemically prepared silver surface. Spectrochim. Acta A 1999, 55, 1641-1660. [CrossRef]

62. Nakamoto, K. Infrared and Raman spectra of inorganic and coordination compounds. Part B: Applications in Coordination, Organometallic, and Bioinorganic Chemistry, 5th ed.; Wiley Interscience Publ.: New York, NY, USA, 1997; pp. 59-62.

63. Lima, J.A.; Freire, P.T.C.; Lima, R.J.C.; Moreno, A.J.D.; Mendes Filho, J.; Melo, F.E.A. Raman scattering of L-valine crystals. J. Raman Spectrosc. 2005, 36, 1076-1081. [CrossRef] 